\title{
An Efficient One-Pot Multicomponent Synthesis of 4-Aza-Podophyllotoxin Derivatives in Ionic Liquid
}

\author{
Hossein Naeimi, ${ }^{1}$ Zahra Rashid, ${ }^{1}$ Amir Hassan Zarnani, $^{2}$ and Ramin Ghahremanzadeh ${ }^{3}$ \\ ${ }^{1}$ Department of Organic Chemistry, Faculty of Chemistry, University of Kashan, Kashan 87317, Iran \\ ${ }^{2}$ Reproductive Immunology Research Center, Avicenna Research Institute, ACECR, Tehran 1936773493, Iran \\ ${ }^{3}$ Nanobiotechnology Research Center, Avicenna Research Institute, ACECR, Tehran 1936773493, Iran
}

Correspondence should be addressed to Ramin Ghahremanzadeh; r.ghahremanzadeh@yahoo.com

Received 6 May 2013; Accepted 2 September 2013

Academic Editor: Andrea Penoni

Copyright (C) 2013 Hossein Naeimi et al. This is an open access article distributed under the Creative Commons Attribution License, which permits unrestricted use, distribution, and reproduction in any medium, provided the original work is properly cited.

\begin{abstract}
A simple, green, and efficient procedure for the synthesis of 4-aza-podophyllotoxin derivatives by using a one-pot three-component reaction of benzaldehydes, 1,3-cyclohexanediones, and anilinolactones in the presence of catalytic amount of alum in 1-butyl3-methylimidazolium triflate as green media is described. This reaction proceeded under mild conditions with the use of an inexpensive and readily available catalyst, high to excellent yields, and simple workup procedure.
\end{abstract}

\section{Introduction}

Multicomponent reactions (MCRs) are one-pot processes in which three or more reactants come together in a single reaction vessel to give a final product containing substantial elements of all the reactants [1-4], and in recent year much attention has been directed toward the one-pot multicomponent reactions, because of their wide range of applications in pharmaceutical chemistry for the production of structural scaffolds and combinatorial libraries for drug discovery [58]. The strategies of MCRs offer significant advantages over conventional linear-type syntheses because of high degree of atom economy, high selectivity, and procedural simplicity due to formation of carbon-carbon and carbon-heteroatom bonds in one-pot procedure [9-11]. MCRs, particularly those performed in green and eco-friendly media, have become increasingly useful tools for the synthesis of chemically and biologically important compounds because of their environmentally friendly atom economy and green characteristics, and the "greening" of global chemical processes has became a major issue in the chemical industry $[12,13]$.

Organic reactions in ionic liquid (IL) media have received the considerable attention of synthetic organic chemists in recent years; IL is an environmentally friendly solvent with unique properties such as high ionic conductivity, nonvolatility, high thermal stability, nonflammability, and miscibility with organic compounds, especially with the heterocyclic compounds [14-17]. Because of these useful properties numerous works have been published in the last decades reporting the possibility to perform several organic reactions and catalyzed processes in these green media [18-20].

1,4-Dihydropyridine compounds are molecules based upon pyridine and this nucleus is one of the significant core structures among the most extensively natural and unnatural heterocyclic compounds, have been recognized as vital drugs for the treatment of cardiovascular diseases, and are well known as calcium channel modulators [21, 22]. 1,4-Dihydropyridine derivatives exhibit a variety of biological properties such as antihypertensive, antianginal [23-25], antitumor [26], anti-inflammatory [27, 28], antitubercular [29], analgesic [30], and antithrombotic [31, 32].

The biological activity of 1,4-dihydropyridine derivatives has led to extensive structural modifications resulting in several clinically useful compounds as a source of valuable drug candidates. Extensive structural modifications have been performed to obtain more potent and less toxic anticancer agents [33-35]. Among these compounds, furo[3,4-b]quinoline$1,8(3 \mathrm{H}, 4 \mathrm{H})$-dione (podophyllotoxin) derivatives, which were reported as powerful DNA topoisomerase inhibitors and inhibit microtubule assembly as an antitumor ligand [36-38], have attracted attention in the recent decade [39-42]. 


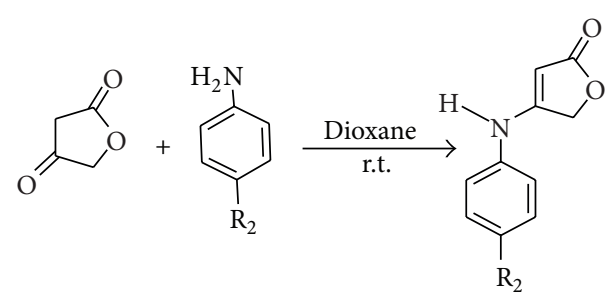

SCHEME 1: Synthesis of anilinolactones.

With the aim to develop efficient synthetic processes using green and eco-friendly methods and to reduce laborious multistep techniques and minimize by-products, we report herein a novel and clean synthesis of some 4-azapodophyllotoxin derivatives in ionic liquid through a threecomponent condensation reaction of benzaldehydes $1,1,3-$ cyclohexanediones 2 , and anilinolactones 3 in the presence of catalytic amount of alum as catalyst.

\section{Results and Discussion}

In this study, firstly, the anilinolactones were prepared from the condensation reaction of tetronic acid with various anilines. As shown in Scheme 1, when tetronic acid reacted with an equimolar amount of various anilines in dioxane solution at room temperature, the corresponding products were obtained in excellent yields, appropriate reaction times, and high purity [43].

In continuation of this research, investigation on the preparation of 4-aza-podophyllotoxin derivatives 4 by using a one-pot three-component condensation reaction of benzaldehydes 1, 1,3-cyclohexanediones 2, and anilinolactones 3 was surveyed (Scheme 2).

To achieve suitable conditions for the synthesis of tetrahydrofuro[3,4-b] quinoline-1,8 $(3 H, 4 H)$-dione derivatives, the reaction of 4 -bromobenzaldehyde $\mathbf{1 d}$, dimedone $\mathbf{2 b}$, and 4 (4-methylphenylamino)furan-2(3H)-one $\mathbf{3 d}$ was chosen as a model reaction (Scheme 3 ). This reaction was first performed in various solvents in the presence of a catalytic amount of $p$ toluene sulfonic acid ( $p$-TSA) as an inexpensive and readily available catalyst at $90^{\circ} \mathrm{C}$. The results are summarized in Table 1.

It was observed that, among all solvents and media, the best result was obtained when 1-butyl-3-methylimidazolium triflate was chosen in the presence of catalytic amount of $p$ TSA at $90^{\circ} \mathrm{C}$. The desired product was obtained in excellent yield and high purity

The catalyst plays a crucial role in the success of the reaction in terms of rate of the reaction and yield. After determining the optimized conditions, we investigated the scope of the catalyst. To find the best catalyst, we screened the model reaction in the presence of different catalysts. The obtained results are outlined in Table 2.

These results indicate that, among all the catalyst systems tested, alum proved to be the most efficient since the reaction could be carried out and the desired product was obtained in excellent yield and high purity. In the absence of the catalyst, the model reaction could be carried out but the product was
TABLE 1: Different polar and nonpolar used solvents, for the synthesis of $4 \mathbf{i}^{\mathrm{a}}$ under reflux conditions.

\begin{tabular}{|c|c|c|c|}
\hline Entry & Solvent & Time (min) & Yield $(\%)^{\mathrm{b}}$ \\
\hline 1 & $\mathrm{MeOH}$ & 120 & 72 \\
\hline 2 & $\mathrm{EtOH}$ & 120 & 75 \\
\hline 3 & 1,4-Dioxane & 120 & 60 \\
\hline 4 & DMF & 120 & 70 \\
\hline 5 & Toluene & 120 & 65 \\
\hline 6 & [bmim][triflate] & 30 & 90 \\
\hline 7 & [bmim] $\mathrm{OH}$ & 30 & 75 \\
\hline 8 & {$[\mathrm{bmim}] \mathrm{PF}_{6}$} & 30 & 88 \\
\hline 9 & {$[\mathrm{bmim}] \mathrm{BF}_{4}$} & 30 & 83 \\
\hline 10 & [bmim]Br & 30 & 80 \\
\hline
\end{tabular}

${ }^{a}$ Reaction conditions: 4-bromobenzaldehyde $\mathbf{1 d}(1 \mathrm{mmol})$, dimedone $\mathbf{2 b}$ ( $1 \mathrm{mmol})$, and 4-(4-methylphenylamino)furan-2(3H)-one $3 \mathbf{d}(1 \mathrm{mmol}), p$ TSA (20 mol\%).

${ }^{\mathrm{b}}$ Isolated yields.

TABLE 2: Diverse used catalyst in a model reaction for the synthesis of $\mathbf{4 i}^{\mathrm{a}}$ in [bmim] [triflate].

\begin{tabular}{lcc}
\hline Entry & Catalyst $(20 \mathrm{~mol} \%)$ & Yield $(\%)^{\mathrm{b}}$ \\
\hline 1 & Alum & 94 \\
2 & p-TSA & 90 \\
3 & $\mathrm{~K}-10$ & 85 \\
4 & $\mathrm{~S} . \mathrm{S} . \mathrm{A}$ & 80 \\
5 & $\mathrm{AlCl}_{3}$ & 55 \\
6 & $\mathrm{Et}_{3} \mathrm{~N}$ & 63 \\
\hline
\end{tabular}

${ }^{a}$ Reaction conditions: 4-bromobenzaldehyde $\mathbf{1 d}(1 \mathrm{mmol})$, dimedone $\mathbf{2 b}$ (1 mmol), and 4-(4-methylphenylamino)furan-2(3H)-one $3 \mathbf{d}(1 \mathrm{mmol})$, IL $(0.2 \mathrm{~mL})$.

${ }^{\mathrm{b}}$ Isolated yields.

obtained in very low yield during $48 \mathrm{~h}$ and gives by TLC analysis only traces of the product.

In order to optimize the more suitable reaction conditions for the preparation of 4-aza-podophyllotoxin derivatives via this novel green chemical approach, quantity of the catalyst required was determined. It was found that, when the reaction was carried out in the presence of 5 mol\% of catalyst, $51 \%$ of yield was obtained. As we increase the percentage of the catalyst to $5 \mathrm{~mol} \%, 10 \mathrm{~mol} \%$, and $15 \mathrm{~mol} \%$, the yields were also found to be increased up to $65 \%, 81 \%$, and $95 \%$, respectively, but beyond $20 \mathrm{~mol} \%$ there is no significant improvement of the rate as well as yield of the reaction, and further increase in the quantity of catalyst did not show appreciable improvement in the yield of product. Thus, $20 \mathrm{~mol} \%$ of catalyst was chosen as maximum quantity of the catalyst for the reaction (Table 3 ).

To optimize the reaction temperature, the reaction of dimedone $\mathbf{1}$, bromobenzaldehyde 2 , and 4-(4-methylphenylamino)furan-2(3H)-one $\mathbf{3}$, as model substrates, was studied in the ionic liquid 1-butyl-3-methylimidazolium triflate in the presence of $20 \mathrm{~mol} \%$ alum, at different temperatures such as room temperature, $70^{\circ} \mathrm{C}, 90^{\circ} \mathrm{C}$, and $110^{\circ} \mathrm{C}$, respectively. The results are summarized in Table 4. 


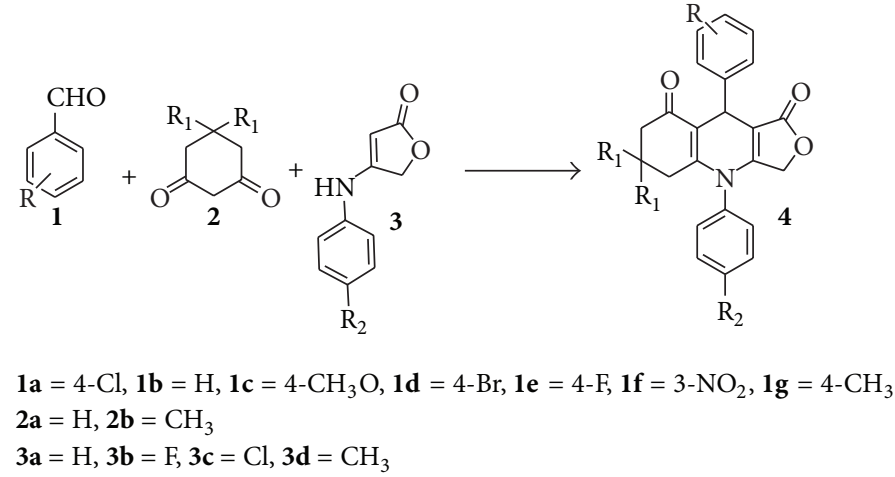

SCHeme 2: Synthesis of 4-aza-podophyllotoxin.<smiles>Cc1ccc(NC2=CC(=O)OC2)cc1</smiles>

SCHEME 3: Model reaction.

TABLE 3: Different amounts of the alum as catalyst for the synthesis of $4 \mathbf{i}^{\mathrm{a}}$.

\begin{tabular}{lcc}
\hline Entry & Alum $(\mathrm{mol} \%)$ & Yield $(\%)^{\mathrm{b}}$ \\
\hline 1 & 5 & 51 \\
2 & 10 & 65 \\
3 & 15 & 81 \\
4 & 20 & 94 \\
5 & 30 & 96 \\
\hline
\end{tabular}

${ }^{a}$ Reaction conditions: 4-bromobenzaldehyde $\mathbf{1 d}(1 \mathrm{mmol})$, dimedone $\mathbf{2 b}$ $(1 \mathrm{mmol})$, and 4 -(4-methylphenylamino)furan-2(3H)-one $3 \mathbf{d}(1 \mathrm{mmol}), \mathrm{IL}$ $(0.2 \mathrm{~mL})$.

${ }^{\mathrm{b}}$ Isolated yields.

As shown in Table 4 , the reaction at $90^{\circ} \mathrm{C}$ proceeded in the highest yield and shortest reaction time among four reaction temperatures tested. No significant increase in the yield of product was observed as the reaction temperature was raised from $70^{\circ} \mathrm{C}$ to $110^{\circ} \mathrm{C}$. Therefore, $90^{\circ} \mathrm{C}$ was chosen for this reaction.

Although the detailed mechanism of the reaction remains to be unclear, a reasonable suggestion is offered in Scheme 4. Firstly, intermediate 5 was formed via the Knoevenagel condensation reaction between aldehyde $\mathbf{1}$ and cyclohexanediones 2 followed by Michael addition reaction between 5 and 3 furnished 6, which upon intermolecular cyclization and dehydration gave rise to 4 .

With the optimized conditions, a variety of benzaldehydes possessing either electron-donating or -withdrawing
TABLE 4: Different reaction temperatures in model reaction for the synthesis of $4 \mathbf{i}^{\mathrm{a}}$.

\begin{tabular}{lccc}
\hline Entry & $\begin{array}{c}\text { Reaction } \\
\text { temperature }\left({ }^{\circ} \mathrm{C}\right)\end{array}$ & Reaction time $(\mathrm{min})$ & Yield $(\%)^{\mathrm{b}}$ \\
\hline 1 & r.t. & 120 & Trace \\
2 & 70 & 60 & 87 \\
3 & 90 & 30 & 94 \\
4 & 110 & 30 & 95 \\
\hline
\end{tabular}

${ }^{a}$ Reaction conditions: 4-bromobenzaldehyde $\mathbf{1 d}(1 \mathrm{mmol})$, dimedone $\mathbf{2 b}$ (1 mmol), and 4-(4-methylphenylamino)furan-2(3H)-one $\mathbf{3 d}(1 \mathrm{mmol}), \mathrm{IL}$ $(0.2 \mathrm{~mL})$, alum $(20 \mathrm{~mol} \%)$

${ }^{\mathrm{b}}$ Isolated yields.

substituents, 1,3-cyclohexanediones, and substituted anilinolactones were next explored to investigate the generality of this methodology; when this reaction was carried out with an aliphatic aldehyde such as propionaldehyde or butanaldehyde in the same conditions ([bmim] [triflate]/alum), the TLC and ${ }^{1} \mathrm{H}$ NMR spectra of the crude reaction mixture showed the presence of a combination of starting materials and numerous by-products that can be synthesized via some reactions such as autocondensation reactions, with the yield of the expected product being very poor. The detailed results were presented in Table 5.

In conclusion, we have developed an extremely efficient and green procedure for the synthesis of biologically active natural product 4-aza-podophyllotoxin derivatives. These products were synthesized previously by the condensation of 


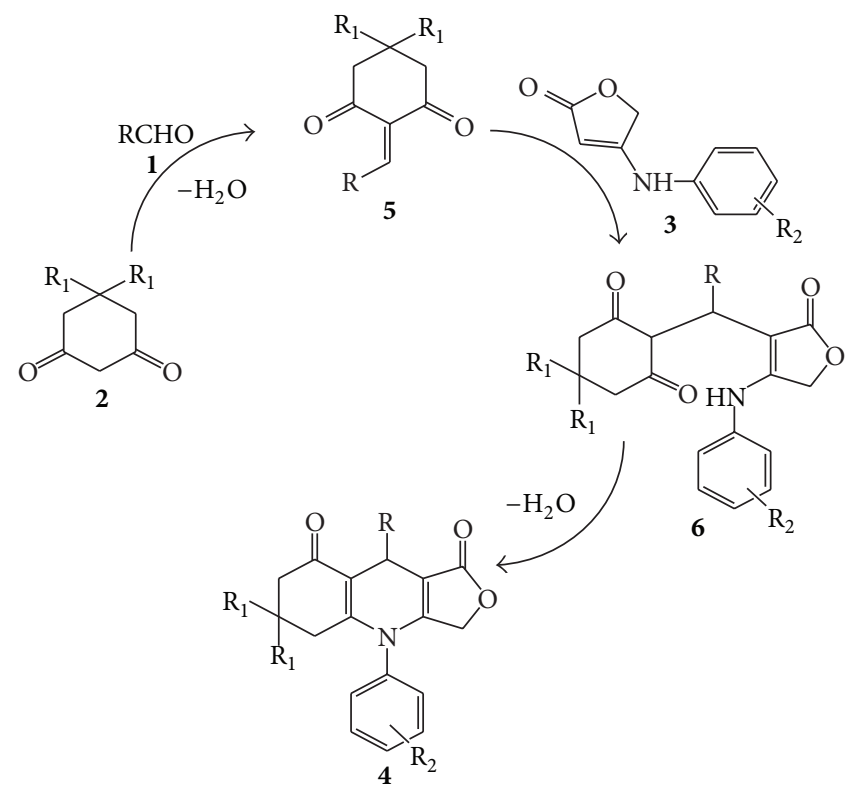

Scheme 4: Proposed mechanism.

benzaldehydes, enaminones, and tetronic acid $[44,45]$. This is the first report of the synthesis of these compounds via a multicomponent condensation of various benzaldehydes, 1,3-cyclohexanediones, and anilinolactones in the presence of Alum as an inexpensive and available catalyst. The advantages of this new method are operational simplicity, high to excellent yields of products in short reaction times, and easy workup procedures.

\subsection{Experimental Part}

General. The chemicals used in this work were obtained from Fluka and Merck and were used without purification. Melting points were measured on an Electrothermal 9200 apparatus. ${ }^{1} \mathrm{H}$ NMR spectra were recorded in DMSO- $\mathrm{d}_{6}$ solvents on a Bruker DRX-400 spectrometer with tetramethylsilane as internal reference. The elemental analyses (C.H.N) were obtained from a Carlo ERBA Model EA 1108 analyzer. The purity determination of the substrates and reaction monitoring were accomplished by TLC on silica-gel polygram SILG/UV 254 plates (from Merck company).

All the products $4(\mathbf{a}-\mathbf{r})$ are known compounds and were characterized by comparison of their ${ }^{1} \mathrm{H}$ NMR spectrum, physical properties, and elemental analyses data with previous synthetic products $[44,45]$.

Typical Procedure for the Preparation of 4-Aza-Podophyllotoxin Derivatives. To a mixture of benzaldehyde ( $1 \mathrm{mmol})$, dimedone $(1 \mathrm{mmol})$, anilinolactone $(1 \mathrm{mmol})$, and alum (20 mol\%), [bmim][triflate] $(0.2 \mathrm{~mL})$ was added. The resulting mixture was stirred at $90^{\circ} \mathrm{C}$ for an appropriate time. After completion of the reaction as indicated by TLC, water $(5 \mathrm{~mL})$ was added and the product was extracted. The reaction mixture was filtered and the precipitate washed with water and recrystallized by EtOH to afford the pure product and was identified by physical and spectroscopic data.

9-(4-Methoxyphenyl)-4-p-tolyl-5,6,7,9-tetrahydrofuro[3, 4-b]quinoline-1,8(3H,4H)-dione (4c). Yield 93\%; $\mathrm{mp}: 255-$ $257^{\circ} \mathrm{C} ;{ }^{1} \mathrm{H}$ NMR (DMSO- $\left.d_{6}\right): \delta 1.67-1.95\left(2 \mathrm{H}, \mathrm{m}, \mathrm{CH}_{2}\right)$, 2.12-2.20 (2H, m, $\left.\mathrm{CH}_{2}\right), 2.21-2.30\left(2 \mathrm{H}, \mathrm{m}, \mathrm{CH}_{2}\right), 2.38(3 \mathrm{H}, \mathrm{s}$, $\left.\mathrm{CH}_{3}\right), 3.75\left(3 \mathrm{H}, \mathrm{s}, \mathrm{CH}_{3}\right), 4.39-4.55\left(2 \mathrm{H}, \mathrm{m}, \mathrm{CH}_{2}\right), 4.79(1 \mathrm{H}, \mathrm{s}$, $\mathrm{CH}), 6.80-747(8 \mathrm{H}, \mathrm{m}, \mathrm{ArH})$. Anal. Calcd for $\mathrm{C}_{25} \mathrm{H}_{23} \mathrm{NO}_{4}: \mathrm{C}$, 74.79; H, 5.77; N, 3.49. Found C, 74.72; H, 5.71; N, 3.55.

9-(4-Methoxyphenyl)-6,6-dimethyl-4-p-tolyl-5,6,7,9-tetrahydrofuro[3,4-b]quinoline-1,8(3H,4H)-dione (4h). Yield 95\%; mp: $257-258^{\circ} \mathrm{C} ;{ }^{1} \mathrm{H}$ NMR (DMSO- $\left.d_{6}\right): \delta 0.85\left(3 \mathrm{H}, \mathrm{s}, \mathrm{CH}_{3}\right)$, $0.95\left(3 \mathrm{H}, \mathrm{s}, \mathrm{CH}_{3}\right), 1.95-2.10\left(2 \mathrm{H}, \mathrm{m}, \mathrm{CH}_{2}\right), 2.20-2.28(2 \mathrm{H}, \mathrm{m}$, $\left.\mathrm{CH}_{2}\right), 2.44\left(3 \mathrm{H}, \mathrm{s}, \mathrm{CH}_{3}\right), 3.75\left(3 \mathrm{H}, \mathrm{s}, \mathrm{OCH}_{3}\right), 4.51-4.58(2 \mathrm{H}$, $\left.\mathrm{m}, \mathrm{CH}_{2}\right), 4.73(1 \mathrm{H}, \mathrm{s}, \mathrm{CH}), 6.81-7.45(8 \mathrm{H}, \mathrm{m}, \mathrm{ArH})$. Anal. Calcd for $\mathrm{C}_{27} \mathrm{H}_{27} \mathrm{NO}_{4}$ : C, 75.50; H, 6.34; N, 3.26. Found C, 75.45; H, 6.41; N, 3.20.

9-(4-Bromophenyl)-6,6-dimethyl-4-p-tolyl-5,6,7,9-tetrahydrofuro[3,4-b]quinoline-1,8(3H,4H)-dione (4i). Yield 94\%; mp: $271-273^{\circ} \mathrm{C} ;{ }^{1} \mathrm{H}$ NMR (DMSO- $\left.d_{6}\right): \delta 0.87\left(3 \mathrm{H}, \mathrm{s}, \mathrm{CH}_{3}\right)$, $0.95\left(3 \mathrm{H}, \mathrm{s}, \mathrm{CH}_{3}\right), 2.04-2.11\left(2 \mathrm{H}, \mathrm{m}, \mathrm{CH}_{2}\right), 2.18-2.23(2 \mathrm{H}, \mathrm{m}$, $\left.\mathrm{CH}_{2}\right), 2.42\left(3 \mathrm{H}, \mathrm{s}, \mathrm{CH}_{3}\right), 4.50-4.54\left(2 \mathrm{H}, \mathrm{m}, \mathrm{CH}_{2}\right), 4.71(1 \mathrm{H}, \mathrm{s}$, $\mathrm{CH})$, 7.27-7.50 (8H, m, ArH). Anal. Calcd for $\mathrm{C}_{26} \mathrm{H}_{24} \mathrm{BrNO}_{3}$ : C, 65.28; H, 5.06; N, 2.93. Found C, 65.30; H, 5.04; N, 2.88.

9-(4-Methoxyphenyl)-6,6-dimethyl-4-phenyl-5, 6,7,9-tetrahydrofuro[3,4-b]quinoline-1,8(3H,4H)-dione (4l). Yield 92\%; mp: $260-262^{\circ} \mathrm{C} ;{ }^{1} \mathrm{H}$ NMR (DMSO- $\left.d_{6}\right): \delta 0.84(3 \mathrm{H}, \mathrm{s}$, $\left.\mathrm{CH}_{3}\right), 0.95\left(3 \mathrm{H}, \mathrm{s}, \mathrm{CH}_{3}\right), 2.02-2.11\left(2 \mathrm{H}, \mathrm{m}, \mathrm{CH}_{2}\right), 2.18-2.25$ $\left(2 \mathrm{H}, \mathrm{m}, \mathrm{CH}_{2}\right), 3.74\left(3 \mathrm{H}, \mathrm{s}, \mathrm{CH}_{3}\right), 4.45-4.61\left(2 \mathrm{H}, \mathrm{m}, \mathrm{CH}_{2}\right)$, $4.75(1 \mathrm{H}, \mathrm{s}, \mathrm{CH}), 6.83-7.58(9 \mathrm{H}, \mathrm{m}, \mathrm{ArH})$. Anal. Calcd for $\mathrm{C}_{26} \mathrm{H}_{25} \mathrm{NO}_{4}$ : C, 75.16; $\mathrm{H}, 6.06 ; \mathrm{N}, 3.37$. Found $\mathrm{C}, 75.11 ; \mathrm{H}$, $6.10 ; \mathrm{N}, 3.43$.

4,9-Bis(4-chlorophenyl)-6,6-dimethyl-5,6,7,9-tetrahydrofuro[3,4-b]quinoline-1,8(3H,4H)-dione (4n). Yield 93\%; mp: 
TABLE 5: Synthesis of 4-aza-podophyllotoxin derivatives (4a-r) ${ }^{\mathrm{a}}$.

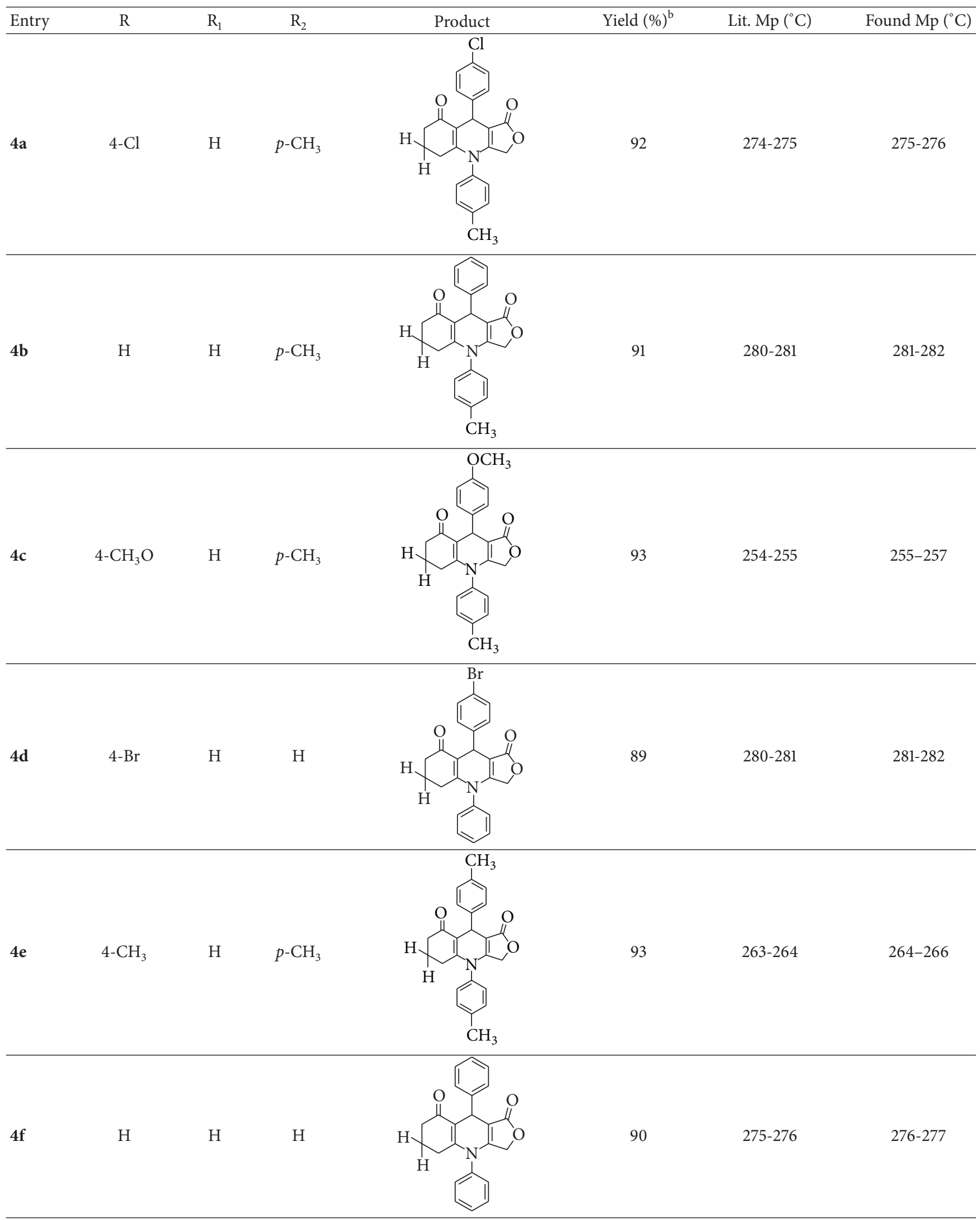


TABle 5: Continued.

\begin{tabular}{|c|c|c|c|c|c|c|c|}
\hline Entry & $\mathrm{R}$ & $\mathrm{R}_{1}$ & $\mathrm{R}_{2}$ & Product & Yield $(\%)^{\mathrm{b}}$ & Lit. $\mathrm{Mp}\left({ }^{\circ} \mathrm{C}\right)$ & Found $\mathrm{Mp}\left({ }^{\circ} \mathrm{C}\right)$ \\
\hline $4 g$ & $4-\mathrm{Cl}$ & $\mathrm{H}$ & $p-\mathrm{Cl}$ & & 92 & $227-228$ & $228-230$ \\
\hline $4 \mathrm{~h}$ & $4-\mathrm{CH}_{3} \mathrm{O}$ & $\mathrm{CH}_{3}$ & $p-\mathrm{CH}_{3}$ & & 95 & $256-257$ & $257-258$ \\
\hline $4 i$ & $4-\mathrm{Br}$ & $\mathrm{CH}_{3}$ & $p-\mathrm{CH}_{3}$ & & 94 & $269-270$ & $271-273$ \\
\hline $4 j$ & $3-\mathrm{NO}_{2}$ & $\mathrm{CH}_{3}$ & $p-\mathrm{CH}_{3}$ & & 92 & $232-233$ & $232-233$ \\
\hline $4 k$ & $4-\mathrm{Cl}$ & $\mathrm{CH}_{3}$ & $\mathrm{H}$ & & 94 & $260-261$ & $262-263$ \\
\hline
\end{tabular}


TABle 5: Continued.

\begin{tabular}{|c|c|c|c|c|c|c|c|}
\hline Entry & $\mathrm{R}$ & $\mathrm{R}_{1}$ & $\mathrm{R}_{2}$ & Product & Yield $(\%)^{\mathrm{b}}$ & Lit. $\mathrm{Mp}\left({ }^{\circ} \mathrm{C}\right)$ & Found $\mathrm{Mp}\left({ }^{\circ} \mathrm{C}\right)$ \\
\hline 41 & $4-\mathrm{CH}_{3} \mathrm{O}$ & $\mathrm{CH}_{3}$ & $\mathrm{H}$ & & 92 & $258-259$ & $260-262$ \\
\hline $4 \mathrm{~m}$ & $3-\mathrm{NO}_{2}$ & $\mathrm{CH}_{3}$ & $\mathrm{H}$ & & 89 & 293-294 & 294-295 \\
\hline $4 n$ & $4-\mathrm{Cl}$ & $\mathrm{CH}_{3}$ & $p-\mathrm{Cl}$ & & 93 & $>300$ & $>300$ \\
\hline 40 & $4-\mathrm{CH}_{3}$ & $\mathrm{CH}_{3}$ & $p-\mathrm{F}$ & & 93 & $281-283$ & $283-285$ \\
\hline $4 p$ & $4-\mathrm{Cl}$ & $\mathrm{CH}_{3}$ & $p$-F & & 92 & $297-299$ & 299-300 \\
\hline $4 q$ & $4-\mathrm{Br}$ & $\mathrm{CH}_{3}$ & $p-\mathrm{F}$ & & 88 & $283-285$ & $285-287$ \\
\hline
\end{tabular}


TABLE 5: Continued.

\begin{tabular}{|c|c|c|c|c|c|c|c|}
\hline Entry & $\mathrm{R}$ & $\mathrm{R}_{1}$ & $\mathrm{R}_{2}$ & Product & Yield $(\%)^{\mathrm{b}}$ & Lit. $\mathrm{Mp}\left({ }^{\circ} \mathrm{C}\right)$ & Found $\mathrm{Mp}\left({ }^{\circ} \mathrm{C}\right)$ \\
\hline $4 \mathbf{r}$ & $4-\mathrm{OCH}_{3}$ & $\mathrm{CH}_{3}$ & $p-\mathrm{F}$ & & 92 & $266-268$ & $268-270$ \\
\hline
\end{tabular}

${ }^{\mathrm{a}}$ Reaction conditions: benzaldehydes $\mathbf{1}(1 \mathrm{mmol})$, cyclohexanediones $2(1 \mathrm{mmol})$, and anilinolactones $3(1 \mathrm{mmol}), \mathrm{IL}(0.2 \mathrm{~mL})$, alum $(20 \mathrm{~mol} \%)$, at $90^{\circ} \mathrm{C}$. ${ }^{\mathrm{b}}$ Isolated yields.

$>300^{\circ} \mathrm{C} ;{ }^{1} \mathrm{H}$ NMR $\left(\mathrm{DMSO}-d_{6}\right): \delta 0.83\left(3 \mathrm{H}, \mathrm{s}, \mathrm{CH}_{3}\right), 0.96(3 \mathrm{H}$, s, $\left.\mathrm{CH}_{3}\right), 2.02-2.11\left(2 \mathrm{H}, \mathrm{m}, \mathrm{CH}_{2}\right), 2.18-2.27\left(2 \mathrm{H}, \mathrm{m}, \mathrm{CH}_{2}\right)$, 4.50-4.63 (2H, m, $\left.\mathrm{CH}_{2}\right), 4.74(1 \mathrm{H}, \mathrm{s}, \mathrm{CH}), 7.35-7.62(8 \mathrm{H}, \mathrm{m}$, ArH). Anal. Calcd for $\mathrm{C}_{25} \mathrm{H}_{21} \mathrm{Cl}_{2} \mathrm{NO}_{3}$ : C, 66.09; $\mathrm{H}, 4.66 ; \mathrm{N}$, 3.08. Found C, 66.14; H, 4.71; N, 3.05.

4-(4-Fluorophenyl)-6,6-dimethyl-9-p-tolyl-5,6,7,9-tetrahydrofuro [3,4-b] quinoline-1,8(3H,4H)-dione (4o). Yield 93\%; mp: $283-285^{\circ} \mathrm{C} ;{ }^{1} \mathrm{H}$ NMR (DMSO- $\left.d_{6}\right): \delta 0.84\left(3 \mathrm{H}, \mathrm{s}, \mathrm{CH}_{3}\right)$, $0.91\left(3 \mathrm{H}, \mathrm{s}, \mathrm{CH}_{3}\right), 1.97-2.10\left(2 \mathrm{H}, \mathrm{m}, \mathrm{CH}_{2}\right), 2.15-2.24(2 \mathrm{H}, \mathrm{m}$, $\left.\mathrm{CH}_{2}\right), 2.26\left(3 \mathrm{H}, \mathrm{s}, \mathrm{CH}_{3}\right), 4.53-4.60\left(2 \mathrm{H}, \mathrm{m}, \mathrm{CH}_{2}\right), 4.75(1 \mathrm{H}, \mathrm{s}$, $\mathrm{CH}), 7.06-7.66(8 \mathrm{H}, \mathrm{m}, \mathrm{ArH})$. Anal. Calcd for $\mathrm{C}_{26} \mathrm{H}_{24} \mathrm{FNO}_{3}$ : C, 74.80; H, 5.79; F, 4.55; N, 3.36. Found C, 74.85; H, 5.75; N, 3.40 .

9-(4-Chlorophenyl)-4-(4-fluorophenyl)-6,6-dimethyl-5,6, 7,9-tetrahydrofuro[3,4-b]quinoline-1,8(3H,4H)-dione (4p). Yield 92\%; mp: $299-300^{\circ} \mathrm{C} ;{ }^{1} \mathrm{H}$ NMR $\left(\mathrm{DMSO}-d_{6}\right): \delta 0.84(3 \mathrm{H}$, $\left.\mathrm{s}, \mathrm{CH}_{3}\right), 0.96\left(3 \mathrm{H}, \mathrm{s}, \mathrm{CH}_{3}\right), 2.01-2.11\left(2 \mathrm{H}, \mathrm{m}, \mathrm{CH}_{2}\right), 2.16-2.22$ $\left(2 \mathrm{H}, \mathrm{m}, \mathrm{CH}_{2}\right), 4.50-4.62\left(2 \mathrm{H}, \mathrm{m}, \mathrm{CH}_{2}\right), 4.76(1 \mathrm{H}, \mathrm{s}, \mathrm{CH})$, 7.32-7.62 (8H, m, ArH). Anal. Calcd for $\mathrm{C}_{25} \mathrm{H}_{21} \mathrm{ClFNO}_{3}$ : C, 68.57; H, 4.83; N, 3.20. Found C, 68.63; H, 4.78; N, 3.22.

9-(4-Bromophenyl)-4-(4-fluorophenyl)-6,6-dimethyl-5,6, 7,9-tetrahydrofuro[3,4-b]quinoline-1,8(3H,4H)-dione (4q). Yield 88\%; mp: $285-287^{\circ} \mathrm{C} ;{ }^{1} \mathrm{H}$ NMR (DMSO- $\left.d_{6}\right): \delta 0.85(3 \mathrm{H}$, $\left.\mathrm{s}, \mathrm{CH}_{3}\right), 0.97\left(3 \mathrm{H}, \mathrm{s}, \mathrm{CH}_{3}\right), 2.00-2.11\left(2 \mathrm{H}, \mathrm{m}, \mathrm{CH}_{2}\right), 2.15-2.20$ $\left(2 \mathrm{H}, \mathrm{m}, \mathrm{CH}_{2}\right), 4.49-4.58\left(2 \mathrm{H}, \mathrm{m}, \mathrm{CH}_{2}\right), 4.74(1 \mathrm{H}, \mathrm{s}, \mathrm{CH})$, 7.28-7.61 (8H, m, ArH). Anal. Calcd for $\mathrm{C}_{25} \mathrm{H}_{21} \mathrm{BrFNO}_{3}$ : C, 62.25; H, 4.39; N, 2.90. Found C, 62.19; H, 4.44; N, 2.88 .

4-(4-Fluorophenyl)-9-(4-methoxyphenyl)-6,6-dimethyl-5, 6,7,9-tetrahydrofuro[3,4-b]quinoline-1,8(3H,4H)-dione (4r). Yield 92\%; mp: $268-270^{\circ} \mathrm{C} ;{ }^{1} \mathrm{H}$ NMR (DMSO- $d_{6}$ ): $\delta 0.88$ $\left(3 \mathrm{H}, \mathrm{s}, \mathrm{CH}_{3}\right), 0.94\left(3 \mathrm{H}, \mathrm{s}, \mathrm{CH}_{3}\right), 1.98-2.04\left(2 \mathrm{H}, \mathrm{m}, \mathrm{CH}_{2}\right)$, 2.15-2.22 $\left(2 \mathrm{H}, \mathrm{m}, \mathrm{CH}_{2}\right), 3.74\left(3 \mathrm{H}, \mathrm{s}, \mathrm{OCH}_{3}\right), 4.48-4.60(2 \mathrm{H}$, $\left.\mathrm{m}, \mathrm{CH}_{2}\right), 4.75$ (1H, s, CH), 6.88-7.60 (8H, m, ArH). Anal. Calcd for $\mathrm{C}_{26} \mathrm{H}_{24} \mathrm{FNO}_{4}$ : C, 72.04; $\mathrm{H}, 5.58 ; \mathrm{N}, 3.23$. Found $\mathrm{C}$, $72.10 ; \mathrm{H}, 5.52 ; \mathrm{N}, 3.25$.

\section{Acknowledgments}

The authors are thankful to the University of Kashan for supporting this work by Grant no. 159148/15 and also gratefully acknowledge the financial support from the Avicenna Research Institute.

\section{References}

[1] A. Dömling, "Recent developments in isocyanide based multicomponent reactions in applied chemistry," Chemical Reviews, vol. 106, pp. 17-89, 2006.

[2] R. V. A. Orru and M. de Greef, "Recent advances in solutionphase multicomponent methodology for the synthesis of heterocyclic compounds," Synthesis, no. 10, pp. 1471-1499, 2003.

[3] C. Hulme and V. Gore, "Multi-component reactions: emerging chemistry in drug discovery from Xylocain to Crixivan," Current Medicinal Chemistry, vol. 10, no. 1, pp. 51-80, 2003.

[4] C. Montagne, J. J. Shiers, and M. Shipman, "Rapid generation of molecular complexity using "sequenced" multi-component reactions: one-pot synthesis of $5,5^{\prime}$-disubstituted hydantoins from methyleneaziridines," Tetrahedron Letters, vol. 47, no. 52, pp. 9207-9209, 2006.

[5] A. Dömling and I. Ugi, "Multicomponent reactions with isocyanides," Angewandte Chemie, vol. 39, no. 18, pp. 3169-3210, 2000.

[6] I. Ugi, "Recent progress in the chemistry of multicomponent reactions," Pure and Applied Chemistry, vol. 73, no. 1, pp. 187191, 2001.

[7] B. B. Touré and D. G. Hall, "Natural product synthesis using multicomponent reaction strategies," Chemical Reviews, vol. 109, no. 9, pp. 4439-4486, 2009.

[8] J. D. Sunderhaus and S. F. Martin, "Applications of multicomponent reactions to the synthesis of diverse heterocyclic scaffolds," Chemistry, vol. 15, no. 6, pp. 1300-1308, 2009.

[9] I. Devi and P. J. Bhuyan, "Sodium bromide catalysed one-pot synthesis of tetrahydrobenzo[b]pyrans via a three-component cyclocondensation under microwave irradiation and solvent free conditions," Tetrahedron Letters, vol. 45, no. 47, pp. 86258627, 2004.

[10] D. M. D'Souza and T. J. Mueller, "Multi-component syntheses of heterocycles by transition-metal catalysis," Chemical Society Reviews, vol. 36, no. 7, pp. 1095-1108, 2007.

[11] C. C. A. Cariou, G. J. Clarkson, and M. Shipman, "Rapid synthesis of 1,3,4,4-tetrasubstituted $\beta$-lactams from methyleneaziridines using a four-component reaction," Journal of Organic Chemistry, vol. 73, no. 24, pp. 9762-9764, 2008.

[12] K. Kumaravel and G. Vasuki, "Four-component catalystfree reaction in water: combinatorial library synthesis of novel 2-amino-4-(5-hydroxy-3-methyl-1H-pyrazol-4-yl)-4Hchromene-3- carbonitrile derivatives," Green Chemistry, vol. 11, no. 12, pp. 1945-1947, 2009. 
[13] S. L. Jain, S. Singhal, and B. Sain, "PEG-assisted solvent and catalyst free synthesis of 3,4-dihydropyrimidinones under mild reaction conditions," Green Chemistry, vol. 9, no. 7, pp. 740-741, 2007.

[14] R. Hagiwara and Y. Ito, "Room temperature ionic liquids of alkylimidazolium cations and fluoroanions," Journal of Fluorine Chemistry, vol. 105, no. 2, pp. 221-227, 2000.

[15] T. Welton, "Room-temperature ionic liquids: solvents for synthesis and catalysis," Chemical Reviews, vol. 99, no. 8, pp. 20712083, 1999.

[16] M. J. Earle and K. R. Seddon, "Ionic liquids: green solvents for the future," Pure and Applied Chemistry, vol. 72, no. 7, pp. 13911398,2000 .

[17] H. Olivier, "Recent developments in the use of non-aqueous ionic liquids for two-phase catalysis," Journal of Molecular Catalysis A, vol. 146, no. 1-2, pp. 285-289, 1999.

[18] J. S. Yadav, B. V. S. Reddy, P. Sreedhar et al., “Three compounent coupling reactions in ionic liquids: one-pot synthesis of isoxazolidines," Journal of Molecular Catalysis A, vol. 270, pp. 160163, 2007.

[19] R. Sheldon, "Catalytic reactions in ionic liquids," Chemical Communications, no. 23, pp. 2399-2407, 2001.

[20] J. Dupont, R. F. De Souza, and P. A. Z. Suarez, "Ionic liquid (molten salt) phase organometallic catalysis," Chemical Reviews, vol. 102, no. 10, pp. 3667-3692, 2002.

[21] F. Bossert, H. Meyer, and E. Wehinger, "4-Aryldihydropyridines, a new class of highly active calcium antagonists," Angewandte Chemie, vol. 20, no. 9, pp. 762-769, 1981.

[22] H. Nakayama and Y. Kasoaka, "Chemical identification of binding sites for calcium channel antagonists," Heterocycles, vol. 42, no. 2, pp. 901-909, 1996.

[23] B. Loev, M. M. Goodman, K. M. Snader, R. Tedeschi, and E. Macko, "Hantzsch-type' dihydropyridine hypotensive agents. 3," Journal of Medicinal Chemistry, vol. 17, no. 9, pp. 956-965, 1974.

[24] F. Bossert, H. Meyer, and E. Wehinger, "4-Aryldihydropyridines, a new class of highly active calcium antagonists," Angewandte Chemie, vol. 20, no. 9, pp. 762-769, 1981.

[25] J. G. Breitenbucher and G. Figliozzi, "Solid-phase synthesis of 4-aryl-1,4-dihydropyridines via the Hantzsch three component condensation," Tetrahedron Letters, vol. 41, no. 22, pp. 4311-4315, 2000.

[26] R. Boer and V. Gekeler, "Chemosensitizers in tumor therapy: new compounds promise better efficacy," Drugs of the Future, vol. 20, no. 5, pp. 499-509, 1995.

[27] V. M. Briukhanov, "The effect of Ca antagonist on the development of inflammatory edema in rats," Clinical and Experimental Pharmacology, vol. 57, pp. 47-49, 1994.

[28] S. Bahekar and D. Shinde, "Synthesis and anti-inflammatory activity of 1-4-dihydropyridines," Acta Pharmaceutica, vol. 52, no. 4, pp. 281-287, 2002.

[29] G. A. Wachter, M. C. Davis, A. R. Martin, and S. G. Franzblau, "Antimycobacterial activity of substituted isosteres of pyridineand pyrazinecarboxylic acids," Journal of Medicinal Chemistry, vol. 41, no. 13, pp. 2436-2438, 1998.

[30] S. Gullapalli and P. Ramarao, "L-type $\mathrm{Ca}^{2+}$ channel modulation by dihydropyridines potentiates $\kappa$-opioid receptor agonist induced acute analgesia and inhibits development of tolerance in rats," Neuropharmacology, vol. 42, no. 4, pp. 467-475, 2002.

[31] C. E. Sunkel, M. Fau de Casa-Juana, L. Santos et al., "4Alkyl-1,4-dihydropyridines derivatives as specific PAF-acether antagonists," Journal of Medicinal Chemistry, vol. 33, no. 12, pp. 3205-3210, 1990.

[32] M. Ono Handkinura, "Effect of $\mathrm{Ca}^{+2}$ antagonist, vasodilators, diltizem, nifedipine, perhexiline and verapamil on platelet aggregation invitro. Arzneim-forsch," Drug Research, vol. 3, pp. 1131-1134, 1981

[33] K. Tomioka, Y. Kubota, and K. Koga, "Design, synthesis, and antitumor activity-absolute configuration relationships of podophyllotoxin aza-analogues," Tetrahedron, vol. 49, no. 9, pp. 1891-1900, 1993.

[34] P. Lienard, J. Royer, J.-C. Quirion, and H.-P. Husson, "Asymmetric synthesis XXIV1: benzoquinolizidine analogues of podophyllotoxin via the $\mathrm{CN}(\mathrm{R}, \mathrm{S})$ method," Tetrahedron Letters, vol. 32, no. 22, pp. 2489-2492, 1991.

[35] G. Poli and G. Giambastiani, "An epiisopicropodophyllin aza analogue via palladium-catalyzed pseudo-domino cyclization," Journal of Organic Chemistry, vol. 67, no. 26, pp. 9456-9459, 2002.

[36] J. van der Eycken, J.-P. Bosmans, D. van Haver et al., "The synthesis of 4-desoxy-2-azapodophyllotoxins," Tetrahedron Letters, vol. 30, no. 29, pp. 3873-3876, 1989.

[37] K. Tomioka, Y. Kubota, and K. Koga, "Synthesis and antitumor activity of podophyllotoxin aza-analogues," Tetrahedron Letters, vol. 30, no. 22, pp. 2953-2954, 1989.

[38] J.-P. Bosmans, J. Van der Eycken, M. Vandewalle, A. Hulkenberg, R. Van Hes, and W. Veerman, "The synthesis of 2-azapodophyllotoxins," Tetrahedron Letters, vol. 30, no. 29, pp. 38773880, 1989.

[39] Y. Hitotsuyanagi, M. Kobayashi, M. Fukuyo, K. Takeya, and H. Itokawa, "A facile synthesis of the 4-aza-analogs of 1-arylnaphthalene lignans chinensin, justicidin B, and Taiwanin C," Tetrahedron Letters, vol. 38, no. 48, pp. 8295-8296, 1997.

[40] Y. Hitotsuyanagi, M. Kobayashi, H. Morita, H. Itokawa, and K. Takeya, "Synthesis of (-)-4-aza-4-deoxypodophyllotoxin from (-)-podophyllotoxin," Tetrahedron Letters, vol. 40, no. 51, pp. 9107-9110, 1999.

[41] C. Tratrat, S. Giorgi-Renault, and H.-P. Husson, "A multicomponent reaction for the one-pot synthesis of 4-aza-2,3-didehydropodophyllotoxin and derivatives," Organic Letters, vol. 4, no. 19, pp. 3187-3189, 2002.

[42] S. Tu, Y. Zhang, J. Zhang et al., "A simple procedure for the synthesis of 4-aza-podophyllotoxin derivatives in water under microwave irradiation conditions," Synlett, no. 17, pp. 27852790, 2006.

[43] Y. Hitotsuyanagi, M. Kobayashi, M. Fukuyo, K. Takeya, and H. Itokawa, "A facile synthesis of the 4-aza-analogs of 1-arylnaphthalene lignans chinensin, justicidin B, and Taiwanin C," Tetrahedron Letters, vol. 38, no. 48, pp. 8295-8296, 1997.

[44] S. Tu, Y. Zhang, R. Jia, B. Jiang, J. Zhang, and S. Ji, "A multi-component reaction for the synthesis of N-substituted furo[3,4-b] quinoline derivatives under microwave irradiation," Tetrahedron Letters, vol. 47, no. 37, pp. 6521-6525, 2006.

[45] C.-L. Shi, H. Chen, and D. Shi, "An efficient one-pot three-component synthesis of tetrahydrofuro[3,4-b] quinoline$1,8(3 \mathrm{H}, 4 \mathrm{H})$-dione derivatives catalyzed by L-proline," Journal of Heterocyclic Chemistry, vol. 49, no. 1, pp. 125-129, 2012. 

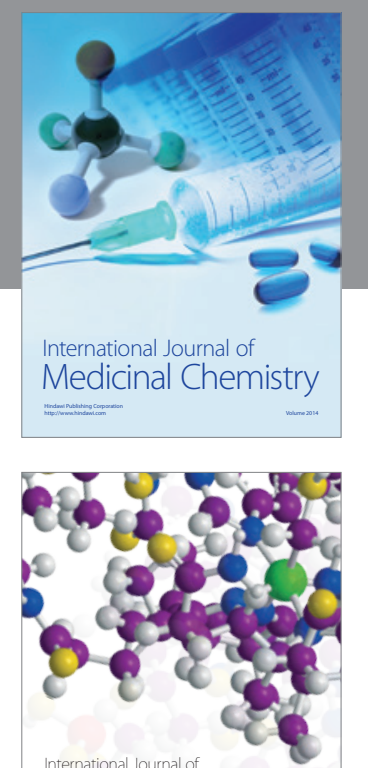

\section{Carbohydrate} Chemistry

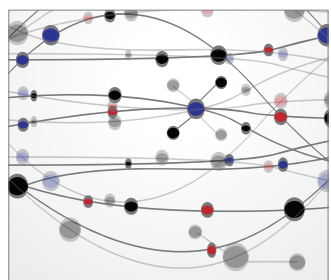

The Scientific World Journal
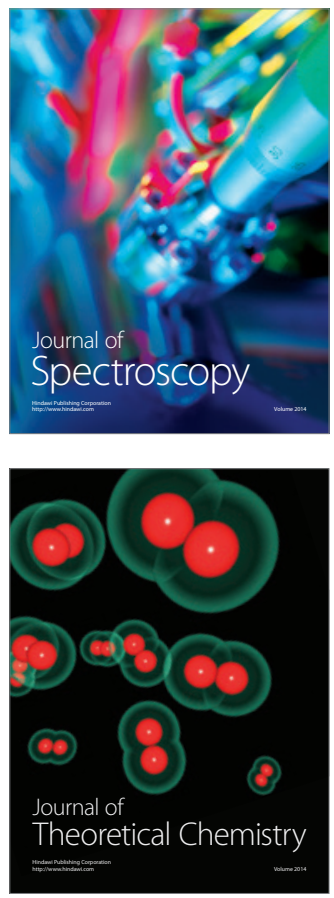
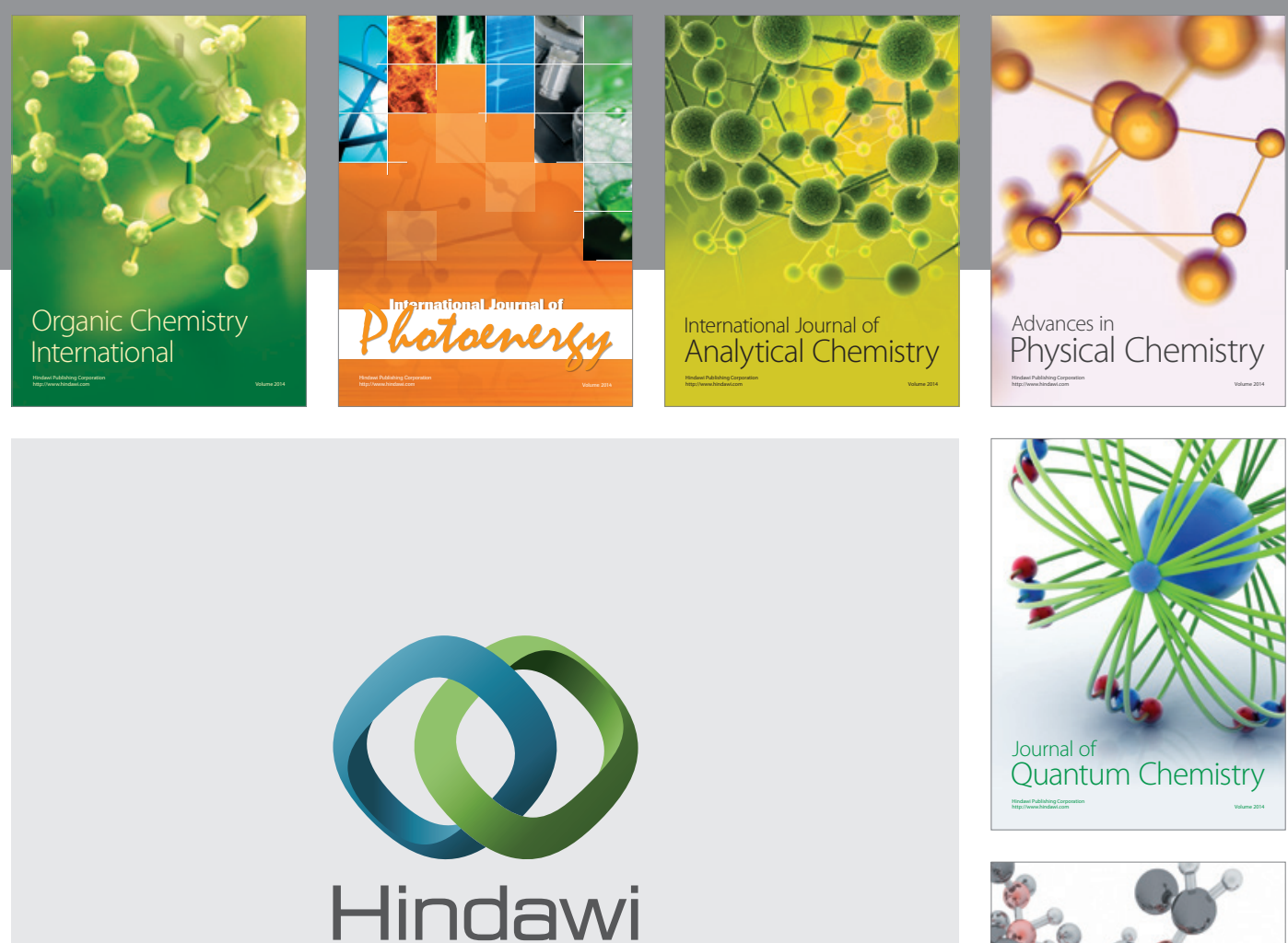

Submit your manuscripts at

http://www.hindawi.com

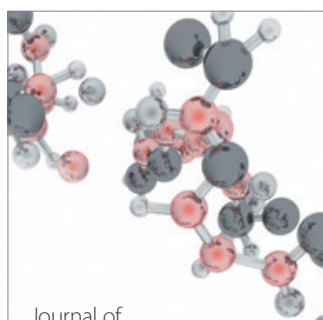

Analytical Methods

in Chemistry

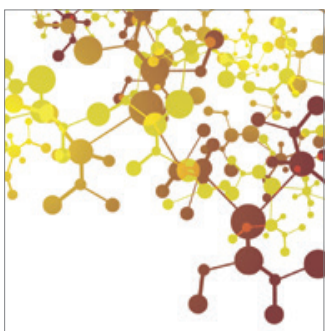

Journal of

Applied Chemistry

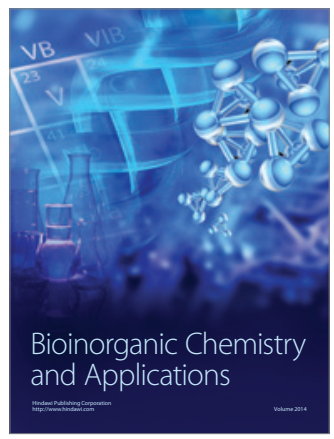

Inorganic Chemistry
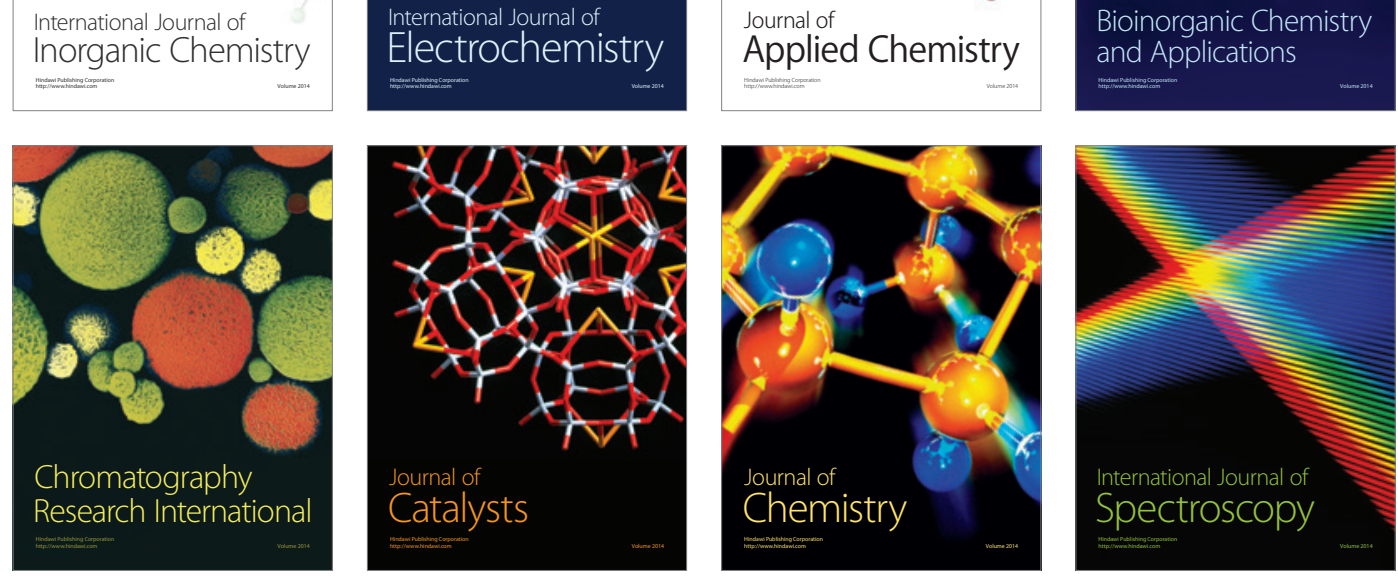